\title{
DARBUOTOJO KONKURENCINGUMO VERTINIMO TEORINIAI ASPEKTAI
}

\author{
Daiva Jurevičiené $\dot{1}^{1}$, Aleksandra Komarova ${ }^{2}$ \\ Vilniaus Gedimino technikos universitetas, Sauletekio al. 11, LT-10223 Vilnius, Lietuva \\ El.paštas: ${ }^{1}$ daiva.jureviciene@vgtu.lt; ${ }^{2}$ komarova_aleksandra@yahoo.com \\ Iteikta 2009-11-25; priimta 2010-02-22
}

\begin{abstract}
Santrauka. Susidūrusios su kvalifikuotos darbo jègos trūkumu, vis daugiau įmonių ryžtasi investuoti ị darbuotojų mokymą ir lavinimą. Organizacijų vadovams kyla problema - kaip įvertinti ir palyginti savo darbuotojų savybes su konkurentų darbuotojais, kokius kriterijus naudoti, vertinant ir lyginant darbo atlikimo efektyvumą ir kaip panaudoti geriausius darbuotojų igūdžius siekiant strateginių organizacijos tikslų. Darbuotojų vertinimas yra kompleksinis, subjektyvus procesas, tad turi būti sprendžiamas sistemiškai. Išryškèja tarpkultūrinès kompetencijos svarba globalioje, žiniomis pagrịstoje visuomenèje. Straipsnyje siūlomi problemos sprendimo metodai, lyginami skirtingi darbuotojų kompetencijos vertinimo būdai. Atlikta mokslinès literatūros analizè. Nagrinejjant darbuotojų vertinimą nustatyti veiksniai, kurie daro įtaką darbuotojų kompetencijai, subjektyvumo grèsmei vertinimo procese. Straipsnyje susisteminti metodai ir priemonès, tinkami darbuotojų konkurencingumui vertinti, atsižvelgiant i objektyvius ir subjektyvius vertinimo veiksnius.
\end{abstract}

Reikšminiai žodžiai: darbuotojo vertinimas, kompetencija, konkurencingumas, mokymo procesas, prieraišumo indeksas, ugdymas, žinios.

\section{THEORETICAL ASPECTS OF EMPLOYEE'S COMPETITIVENESS ASSESSMENT}

\author{
Daiva Jurevičiené $\dot{1}^{1}$, Aleksandra Komarova ${ }^{2}$ \\ Vilnius Gediminas Technical University, Sauletekio al. 11, LT-10223 Vilnius, Lithuania \\ E-mails: ${ }^{1}$ daiva.jureviciene@vgtu.lt; ${ }^{2}$ komarova_aleksandra@yahoo.com \\ Received 25 November 2009; accepted 22 February 2010
}

\begin{abstract}
Faced with a shortage of skilled labour, more and more companies invest in training and education of their personnel. Organizational managers are confronted with the problem how to assess and compare employee's advantages and disadvantages with its competitors, which criteria could be used to evaluate and compare the work performance and how to use best skills of employees to achieve organization's strategic objectives. Employee evaluation is a complex, subjective process that needs to be solved systematically. Intercultural competence becomes important due to globalization, knowledge-based society. This article offers managerial methods to solve the problem, compares different ways used to assess employee's competence. Scientific literature analysis is performed. Analysis of staff assessment revealed the factors that influence the competitiveness of employees, the threat of subjectivity in the evaluation process, evaluation methods diversity. The most important issues and methods to be used to tackle them are determined.
\end{abstract}

Keywords: competence, competitiveness, education, evaluation of employee, knowledge, loyalty index, training process. 


\section{Ivadas}

Kuriant dinamišką ir konkurencingą ekonomiką ypač svarbūs tampa igūdžiai, siekiant didesnio užimtumo žiniomis grindžiamoje visuomeneje. Vienas iš ES prioritetų - padidinti investicijas ị žmones ir mokymą, kurių poreikị lemia spartus smulkiojo, vidutinio verslo sektoriaus augimas, rinkos globalizacija, tarptautinių ryšiu plètra, informaciniu technologiju kaita ir skverbimasis ị visus ūkio sektorius. Dèl kvalifikuotos darbo jègos trūkumo vis daugiau imonių pačios ryžtasi investuoti i darbuotojų kvalifikaciją ir išsilavinimą. Tačiau organizacijų vadovai susiduria su darbuotojų privalumų ir trūkumų ịvertinimo problema, rinkdamiesi kriterijus, kuriais remiantis reiketų nustatyti ir palyginti darbo atlikimo efektyvumą, kaip tinkamai panaudoti vertingąsias savo darbuotojų savybes organizacijos strateginiams tikslams pasiekti. Todèl pagrindine kliūtimi tampa darbuotojo darbo atlikimo efektyvumo vertinimas, jo kompetencijos ar kitų konkurencingumo elementu kiekybinè išraiška. Šiame darbe objektu pasirinktas darbuotoju konkurencingumo vertinimas ir susisteminamos darbuotojų konkurencingumo vertinimo galimybès.

Straipsnio tikslas - apibendrinus veiksnius, darančius itaką darbuotojų konkurencingumui, nustatyti taikytinus darbuotojų konkurencingumo vertinimo būdus. Tyrimo metodai - mokslinès literatūros lyginamoji analizè ir sintezè, loginis apibendrinimas.

Išanalizavus įvairią mokslinę literatūrą galima teigti, kad dar nèra sukurta tinkamo, objektyvaus darbuotojų konkurencingumo ivvertinimo modelio, pastebima subjektyvumo grésmė vertinimo procese, bet autoriai sutaria, kad darbuotojų kompetencija yra reikšminga įmonių konkurencinio pranašumo sudedamoji dalis globalios, žiniomis pagristos ekonomikos laikais.

\section{Darbuotojų konkurencingumo problemos sisteminè interpretacija}

Darbuotojų konkurencingumo vertinimo problemą galima nagrinèti remiantis sistemų teorija (1 pav.).

Dalis individo turimų žinių (kompetencijos), naudojamų darbe, didina organizacijos konkurencingumą, o kuo daugiau konkurencingų organizacijų, tuo konkurencingesnè ūkio šaka ir pati valstybè ( 2 ir 3 pav.).

Žmogus kaip individas priklauso biologinei (pagal savo prigimtị) natūraliai (pagal susidarymo būdą) sistemai. Kuo

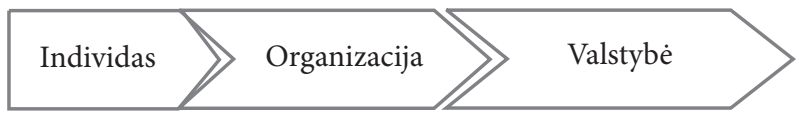

1 pav. Individo ir valstybės konkurencingumo sąsajos

Fig. 1. Individual - State Competitiveness Interface

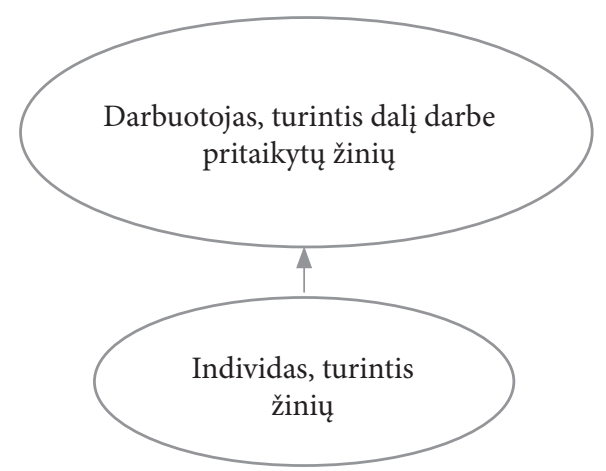

2 pav. Individas-darbuotojas

Fig. 2. Individual - Employee

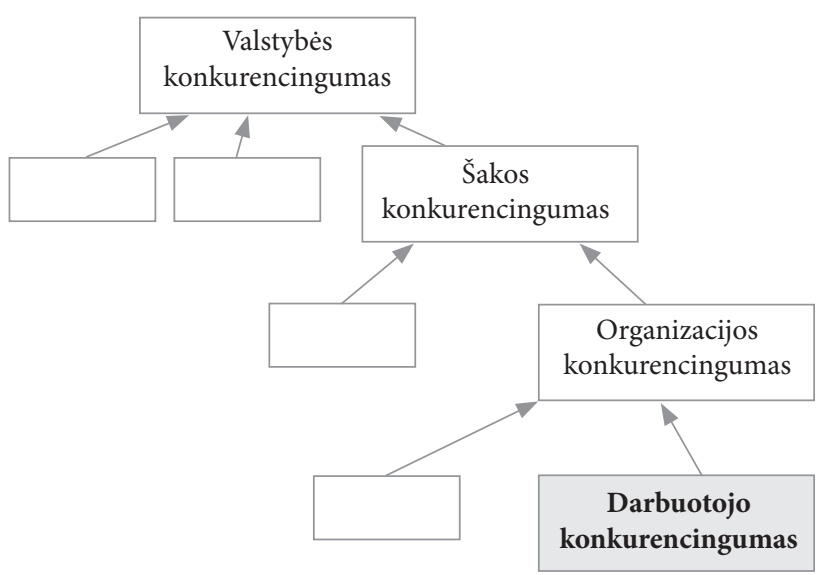

3 pav. Valstybès ir darbuotojo konkurencingumo sąsajos

Fig. 3. State - Employee's Competitiveness Interface

talentingesnis yra individas, tuo didesnè tikimybė, kad daugiau turimų žinių ir ig ūdžių pritaikys darbe. Darbdaviai turi sudaryti tinkamas sąlygas (motyvavimas, atlygis, pasitikejimas, kūrybiškumo skatinimas, laisve pačiam priimti sprendimą ir pan.), kad darbuotojas norètų ir galètų pritaikyti savo patirtį, žinias, profesinius ịgūdžius darbe. Neretai pasitaiko, kad darbuotojai, dalyvavę mokymo kursuose, negali pritaikyti darbo vietoje naujų žinių, problemų sprendimo būdų, tad darbdaviams tokių kursų organizavimas būna neefektyvus ar net nuostolingas.

Valstybės ir darbuotojo konkurencingumo sąveika išsamiau perteikiama per šakos ir organizacijos konkurencingumo tarpines grandis, kur darbuotojas yra žemiausia, nedaloma pakopa. Pripažistama, kad šalių ekonomikos vystymąsi lemia šie reiškiniai: mokymasis, tyrimai, inovacijos, bendradarbiavimas su kitomis valstybèmis. Izoliuotos ekonomikos valstybės nèra pažangios ir nèra pajejgios konkuruoti tarptautiniu mastu. Taigi aukštos kvalifikacijos 
darbuotojų migracija yra vienas iš svarbiausių fenomenų, prisidedančių prie žiniomis grisstos ekonomikos šalių progreso. Pabrèžtina, kad anksčiau šis reiškinys buvo analizuojamas kaip protų nutekèjimas ir protų telkimas, tačiau dabar tokị fenomeną labiau derètų vadinti protų cirkuliacija. Konceptualus protų cirkuliacijos suvokimas yra interpretuojamas kaip protų nutekejimo ir protų telkimo fenomenų evoliucijos pasekmé. Teigiama, kad šių keturių veiksnių derinys: industrinès struktūros kūrimas (kur bendradarbiaujančios įmonès dalijasi darbais ir inovacijomis), pasitikejjimo, mokymosi ir verslumo skatinimas, rizikos kapitalo pritraukimas, valstybių vyriausybių vaidmens finansuojant privatųji sektorių didinimas (taip skatinant technologijų perdavimą), yra sèkmės faktorius, skatinantis protų cirkuliaciją (Daugèlienė, Marcinkevičienè 2009).

Darbuotojų konkurencingumas apima tam tikrus elementus, susijusius tiek su darbuotojų savybèmis, tiek su darbo vietos ypatybėmis (4 pav.).

Daugelis autorių (Balčiūnas et al. 2006; Boreišaite et al. 2006; Budaitè, Petkevičiūtè 2005; Darškuvienè et al. 2008; Gudauskaitė 2007; Zinkevičiūtè 2006 ir kt.), nagrinėjančių šią problemą, vartoja ne "konkurencingumo“ terminą, o „kompetenciją“. Dalis autorių net neskiria ribos tarp kvalifikacijos ir kompetencijos, šias sąvokas vartoja kaip sinonimus (savo tyrimuose pažymejo Skučienè 2008).

Galima išskirti tris pagrindinius nagrinëjamos problemos elementus: darbuotoją, vertinimo kriterijus, pagal kuriuos nustatomas jo konkurencingumas; ir pats vertinimo procesas, kurie tarpusavyje sąveikauja (5 pav.). Skirtingoms pareigybèms taikomi skirtingi vertinimo kriterijai, reikalavimai.

Pirmasis žingsnis, analizuojant žmogiškuosius išteklius, yra organizacijos žmonių išteklių auditas - strateginè

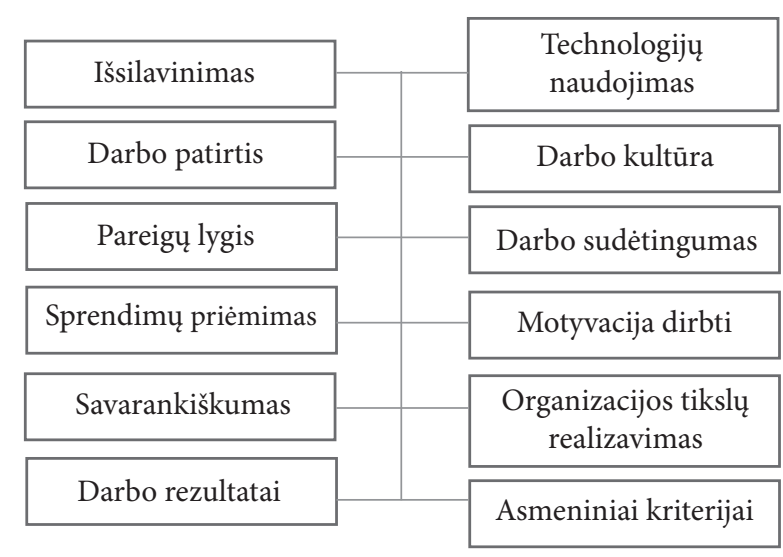

4 pav. Sudedamosios darbuotojo konkurencingumo dalys (remiantis Bivainis, Morkvėnas 2008)

Fig. 4. Components of Employee Competitiveness (according to Bivainis, Morkvènas 2008)

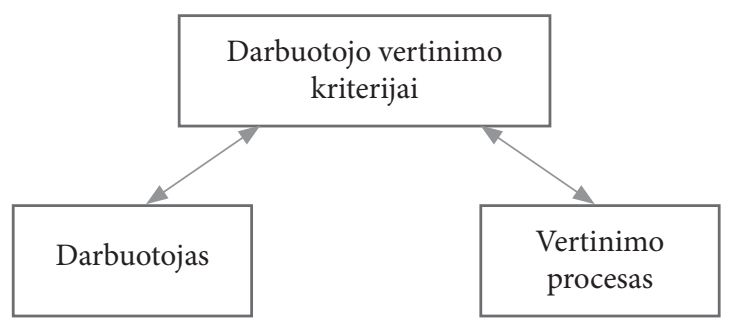

5 pav. Pagrindiniai darbuotojo vertinimo problemos kaip sistemos elementai

Fig. 5. The main elements of employee evaluation problem

analizė, leidžianti gauti pagrindinę informaciją apie organizacijos žmones ir politiką jų atžvilgiu bei detaliai ištirti žmonių išteklių valdymo funkcijos indèlị ir vaidmenị į organizacijos strategijos kūrimą ir ígyvendinimą (Vasiliauskas 2004). Organizacijos žmonių išteklių analizès rezultatus verta palyginti su pagrindinių konkurentų duomenimis. Daugianacionalinèms bendrovèms verta išnagrinèti tarptautinius žmonių išteklių aspektus.

Taigi darbuotojo konkurencingumo problemą galima išskaidyti i ̨ smulkesnes problemas: kas lemia ir sudaro darbuotojo konkurencingumą, kaip ji didinti, kaip nustatyti vertinimo kriterijus ir išvengti subjektyvumo, taikant ne tik kokybinius, bet ir kiekybinius metodus. Svarbu išskirti jo poreikius, motyvus, elgesị (darbinę veiklą, rezultatus), galimybes (žinias ir fizinę būklę), atsakomybę ir gebejiimus (kompetenciją), nes šie elementai veikia vienas kitą ir lemia jo konkurencingumą (6 pav.).

Darbuotojo poreikių patenkinimą, stimulą tobulèti, kelti savo kompetenciją veikia ir pati organizacija, kurioje jis dirba: motyvavimo sistema, organizacijos vertybès, kultūra, personalo valdymo koncepcija, vadovavimo meto-

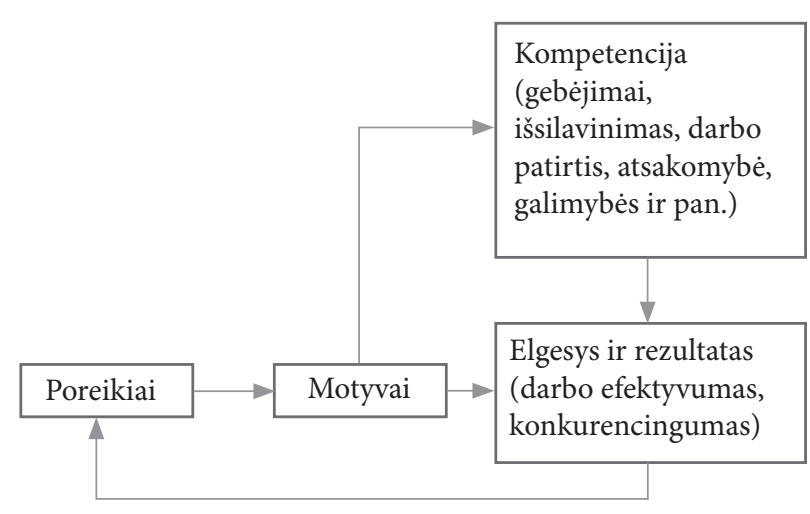

6 pav. Vidiniai elementai, darantys įtaką darbuotojo konkurencingumui

Fig. 6. Internal elements that influence the competitiveness of employee 
dai, plètros strategija. Dažnai deramai ịvertinti darbuotoją trukdo tokie vidiniai veiksniai, kaip nepakankama pačiu vertintojų kompetencija, subjektyvumas, išankstiniai nusistatymai, netgi laiko stygius, kai išsamiai neanalizuojamos darbo vietos, pareigybès - kokie iš tiesų kriterijai turètų būti taikomi.

Galima nustatyti keletą išorinès aplinkos veiksnių, kurie veikia darbuotojo pasiryžimą būti konkurencingam, kelti savo kompetenciją (1 lentelè).

Darbuotoją tobulèti, siekti karjeros aukštumų, būti savo srities specialistu labiausiai skatina vidiniai veiksniai, tokie kaip vertybès, lūkesčiai, poreikiai, o organizacija ir valstybė savo politika turètų motyvuoti ir sudaryti tam visas galimybes.

\section{Pagrindinès atliktų darbuotojų kompetencijų tyrimų kryptys}

Apžvelgus pastarųjų metų atliktus tyrimus darbuotojų konkurencingumo vertinimo srityje, galima susisteminti pagrindinius taikytus metodus ir ịvertinti išryškejjusias šios problemos sprendimo tendencijas (7 pav.).

Mokslininkai tyrè konsultanto pasirengimo ir savybiu svarbą vertinimo procese, finansų specialisto, buhalterio, vadybininko kompetencijas, ES šalių organizacijų vadovų karjeros veiksnius. Dauguma autorių savo empiriniams tyrimams naudoja anketinę darbdavių ar darbuotoju apklausą, klausimynus, interviu (kokybinius metodus), o gautus rezultatus apdoroja matematinès statistikos meto-

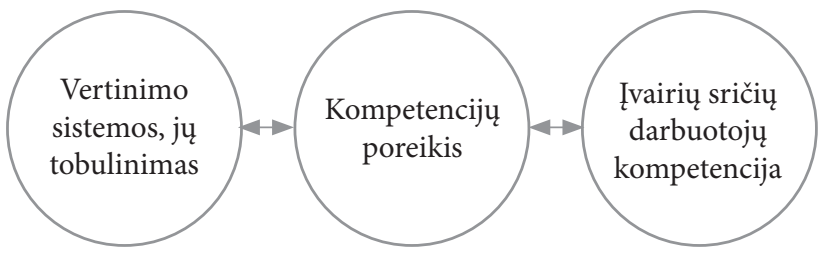

7 pav. Atliktų darbuotojų kompetencijų tyrimų kryptys (Čepinskis, Rudytė 2007; Daukšienè et al. 2008; Juodvalkytė 2006; Lobanova et al. 2009; Gruževskis et al. 2007; Zakarevičius, Žukauskas 2008 ir kt.)

Fig. 7. Research Areas on the Employee's Competence (according to Čepinskis et al. 2007; Daukšienè et al. 2008; Juodvalkytė 2006; Lobanova et al. 2009; Gruževskis et al. 2007; Zakarevičius, Žukauskas 2008, etc.)

dais, koreliacine regresine analize. Vertindami darbuotojų kompetencijas, autoriai išskiria tarpkultūrinès kompetencijos (tiek darbuotojo, tiek organizacijos) svarbą šiuolaikinès globalizacijos laikotarpiu bei komunikavimo kompetenciją (Budaitė, Petkevičiūtè 2005; Gudžiūnienè 2006; Keršienè, Savanevičienè 2009). Žinių ekonomikos visuomenėje ypatingas dèmesys kreipiamas $\mathfrak{i}$ intelektini darbuotojo kapitalą (Boreišaitè et al. 2006). Nustatant kompetencijas, būtinas kritiškas požiūris, nes jos vertinamos statikos būklès, neatsižvelgiant $\mathfrak{i}$ kompetencijų poreikị ateityje, pasikeitus aplinkybèms, kurios bus būtinos darbuotojui ne tik siekiant išlaikyti turimą poziciją i̇monèje, bet kurios

1 lentelè. Išorès veiksnių poveikis darbuotojo kompetencijos kèlimui

Table 1. Influence of external factors on the elevation of employee's competence

\begin{tabular}{|c|c|}
\hline Politiniai veiksniai & $\begin{array}{l}\text { Vyriausybės politika, įstatymai, taikant mokesčių lengvatas ịmonėms, } \\
\text { finansuojančioms savo darbuotojų mokymus, kompetencijų kèlimą }\end{array}$ \\
\hline Ekonominiai veiksniai & $\begin{array}{l}\text { Darbuotojų pasiūla ir paklausa, vidinė konkurencija rinkoje, kuri gali skatinti } \\
\text { didinti savo konkurencingumą; gyventojų pajamos, kokią dalị jie patys galètų skirti } \\
\text { kompetencijos kèlimui }\end{array}$ \\
\hline Socialiniai veiksniai & $\begin{array}{l}\text { Darbuotojo šeimos palaikymas, visuomenès lūkesčiai, vyraujančios mokymosi } \\
\text { tendencijos, mokslo laipsnio prestižas }\end{array}$ \\
\hline Technologiniai veiksniai & $\begin{array}{l}\text { Naujų technologijų atsiradimas, sparti jų kaita, darbo vietų automatizavimas, verčiantis } \\
\text { tobulèti ir mokytis visą gyvenimą, greitai prisitaikyti prie pokyčių }\end{array}$ \\
\hline Švietimo sistema & Galimybès mokytis, kelti kvalifikaciją, persikvalifikuoti \\
\hline Profesinès sąjungos & $\begin{array}{l}\text { Darbuotojų teisių gynimas, darbdavių požiūris ị bendradarbiavimą bei darbuotojų } \\
\text { kompetencijų kėlimą }\end{array}$ \\
\hline $\begin{array}{l}\text { Migracija, globalizacijos } \\
\text { procesai }\end{array}$ & Darbo jëgos iš kitų valstybių sudaroma išorinè konkurencija, skatinanti tobulèti \\
\hline Besiplečianti aptarnavimo sfera & $\begin{array}{l}\text { Skatinanti orientaciją i klientą, kokybę, bendravimo igūužių lavinimą - socialinę } \\
\text { kompetenciją }\end{array}$ \\
\hline
\end{tabular}


reikalingos siekiant tolesnès karjeros (Darškuvienè et al. 2008). Lietuvos organizacijose dar trūksta aiškiai nustatytų karjeros planavimo, pareigybių reikalavimų, standartų (Janušauskas, Makštutis 2007). Tik $18 \%$ personalo vadovų vykdo darbuotojų mokymus ir kvalifikacijos tobulinimus, nors $60 \%$ apklaustųjų patvirtino, kad tai turètų būti daroma (Lobanova 2009). Darbdaviai labiau rūpinasi kvalifikuotų darbuotojų įdarbinimu savo įmonèje (62,2 \%), bet ne esamu mokymu (Stankevičienè et al. 2008). 2004 m. atlikto tyrimo duomenimis, Lietuvos organizacijos, priklausomai nuo darbuotojų skaičiaus, mokymui skiria $0,01-1 \%$ visų išlaidų, kiek daugiau - $10 \%$ - skiria ịmonès, kuriose dirba 16 darbuotojų, $5 \%$ - 240 darbuotojų, o išlaidos vienam darbuotojui svyruoja nuo 60 Lt iki 2000 Lt (Kumpikaitė 2007). 19,4 \% organizacijų mokymasis yra nukreiptas įžmogiškųjų išteklių poreikius, $22,2 \%$ - ị organizacijos strategiją ir individualius tikslus, o $20 \%$ organizacijų mokymosi procesą suvokia kaip išlaidas, o ne kaip investavimą (Kumpikaite 2008). Dauguma vadybininkų tobulejja projektų vykdymo ir kvalifikacijos kèlimo kursuose, specialistams naudingas grupinis darbas ir diskusijos, prižiūrint konsultantui, o darbininkai kvalifikaciją kelia stebėdami, kaip dirba kiti, diskutuodami, dirbdami grupėse ir tobulindamiesi kursuose (Čiarnienè, Kumpikaitè 2008). Svarbi yra ne tik formalioji, bet ir savaiminiu neformaliuoju būdu igyta kompetencija, problema kyla diegiant, tobulinant jos vertinimą, pripažinimo sistemą (Stasiūnaitienè 2008). Dalis autorių išskiria erudicijos (apsiskaitymo), išteklių valdymo (esant ribotiems ištekliams ir neribotiems poreikiams) svarbą (Bersènaitė et al. 2009; Zakarevičius, Župerkienè 2008). Atrastas ryšys tarp naujo vadovo savybių ir organizacijos sèkmès: labiau išsilavinęs vadovas linkęs igyvendinti daugiau pokyčių, kuo jaunesnis - daugiau technologinių pokyčių, pabrèžiamas vadovo gebejimas kurti viziją (Buožiūtè-Rafanavičienẻ et al. 2009).

Svarbus įmonès, kuriančios konkurencinị pranašumą, veiksnys yra sisteminis mąstymas, darbuotojo kompetencijos svarba strateginiams sprendimams, komandiniam darbui, tad organizacija turètų būti lanksti, jei nori išlaikyti žinias (Gedvilienè, Kuncaitis 2008; Zinkevičiūtè 2006). Darbdaviai pageidauja, kad jų darbuotojai lavintų profesinę kompetenciją, užsienio kalbų mokejimą (2003 m. tik $20 \%$ Lietuvos gyventojų gana gerai kalbèjo angliškai, kad galètų bendrauti, ir Lietuva pagal ši rodiklị atsiliko nuo Čekijos, Estijos, Latvijos, Lenkijos ir Slovenijos) (Dobson, Sennikova 2007), ir ITT išmanymą (Rutkienè et al. 2006). ITT išmanyti aktualu, nes naujų informacinių technologijų amžiuje žmogiškasis veiksnys išlieka svarbus - eksperimentiniai tyrimai parodė žmogaus, dalyvaujančio sprendžiant daugiakriterinio optimizavimo uždavinį, kompiuterio ir žmogaus sąveikai naudojant kompiuterių tinklą, svarbą (Petkus et al. 2009). Veiklos žinių komponentas apibrèžiamas kaip būtina trijų dalių visuma: žinių valdymo metodai, žinios apie IT paslaugas ir priemones bei veiklos valdymo žinios (Gudas 2009). Jauni ir vyresnio amžiaus gyventojai skirtingai supranta mokymąsi (Skučienè 2008; Rutkienè et al. 2006). Kai kurie autoriai, kaip jau minèta, dažnai neskiria kvalifikacijos nuo kompetencijos.

Aktuali problema yra sąsaja tarp darbuotojo kompetencijos (konkurencingumo) ir jo igyto išsilavinimo. Pagal igytą specialybę dirba tik 64,8\% humanitarinių mokslu absolventų, iš igijusių magistro laipsnị - pagal savo specializaciją dirba $93 \%$, o pasiruošimas profesinei veiklai siekia $68,6 \%$, darbo užmokestis igytą išsilavinimą atitinka $29 \%$. Labiausiai profesinę veiklą atitinka menų magistrantūros $(64,6 \%)$, mažiausiai - fizikos mokslų (44 \%), socialinių ir humanitarinių mokslų magistrantūros absolventai - 5355 \% (Ginevičius, Ginevičienè 2009).

Kai kurių autorių nuomone, nuosmukio metu lemiamą vaidmeni i̇monių ateičiai vaidina finansų vadovų kompetencija (Clarke 2009). Organizacijoje, kurioje dirba įvairiu kartų darbuotojai, riekia atsižvelgti i jų vertybių, motyvų skirtumus ir skatinti juos tarpusavyje bendradarbiauti, keistis patirtimis ir žiniomis (The Multigenerational... 2009); darbuotojai turètų labiau pažinti savo įmonès klientus, nes jie klaidingai galvoja apie klientų vertinamas įmonès paslaugas, o tai trukdo tobulèti (Rostamy 2009). Kiti autoriai mano, kad darbuotojo požiūris, nusistatymai yra svarbesni negu jo kompetencija, nes kompetenciją galima ugdyti mokinant, o nuostatos sunkiai keičiamos. Darbuotojų igūdžių stoka jaučiama ir JAV (dabartiniams ir ateities darbams reikia daugiau nerutininių analitinių, interaktyviu užduočių meistriškumo, įmonèse nèra nustatytų tikslių kompetencijų, karjeros modelių (Minton-Eversole 2009). ES skatina pritraukti imigrantus, sprendžiant kvalifikuotos darbo jègos trūkumo problemą (Mokymo funkcijos stiprinimas... 2006).

\section{Darbuotojų prieraišumo indeksas}

Rytų šalyse vyrauja kolektyvinè kultūra, kiekvienas žmogus suvokiamas kaip organizacijos dalis ir dèmesys telkiamas ị tai, kaip jis gali patenkinti organizacijos poreikius, o Vakaruose dominuoja kitoks požiūris - žmonès jaučiasi ne tiek organizacijos dalis, bet ją traktuoja kaip priemonę savo individualiems siekiams realizuoti.

Pasaulyje TRI ${ }^{\star} \mathrm{M}^{1^{\star}}$ metodu pagrịstus darbuotojų nuomonès tyrimus taiko tokios kompanijos, kaip "Nokia“, „Audi“, „Siemens“, „McDonald‘s“. Lietuvoje šiuos tyrimus pasitelkia didžiosios bendrovès. Darbuotojo prieraišumo indeksas $\mathrm{TRI}^{\star} \mathrm{M}$ lygina emocinị prisirišimą ir motyvacijos

\footnotetext{
$1^{*} \mathrm{TRI}^{\star} \mathrm{M}$ - modelis, pavadintas pagal pagrindinius tris $\mathrm{M}$ principus: matuoti (ang. Measuring), valdyti (ang. Managing), stebèti (ang. Monitoring).
} 
lygį su darbo sąlygomis. TRI ${ }^{\star} \mathrm{M}^{\mathrm{m}}$ modelis apima tris pagrindinius principus: matuoti - valdyti galima tik tai, kas yra išmatuojama ir suprantama; valdyti - matavimo rezultatus perkelti ị veiksmus, igyvendinti reikiamus pokyčius; stebèti - atlikti tęstinị igyvendintų veiksmų rezultatų ir pasekmių vertinimą (TRI ${ }^{\star} \mathrm{M}$ - įmonés... 2009). TRI ${ }^{\star} \mathrm{M}$ tipologijos instrumentas leidžia aprašyti analizuojamų interesų grupių struktūrą lojalumo ir pasitenkinimo įmone pagrindu (8 pav.).

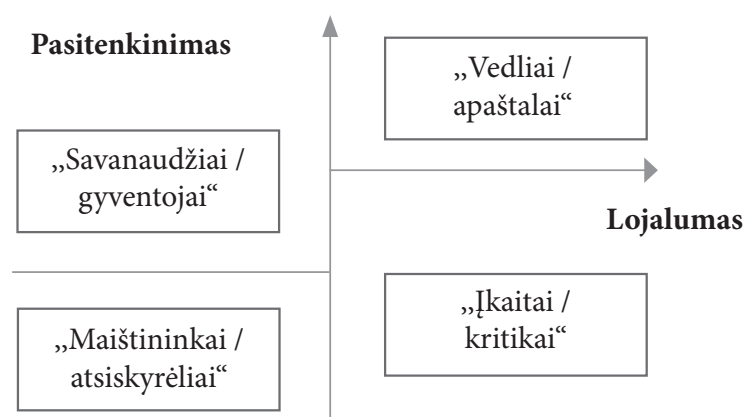

8 pav. Prieraišumo indekso tipologija $\left(\mathrm{TRI}^{\star} \mathrm{M}\right.$ - įmonės... 2009)

Fig. 8. Typology of Loyalty Index (TRI*M - i̇monès... 2009)

Pavyzdžiui, savo darbuotojų prieraišumo indeksą yra paskelbusi „Bitès“ grupè. $2006 \mathrm{~m}$. vadinamasis bendrovès $\mathrm{TRI}^{\star} \mathrm{M}$ indeksas, apibrèžiantis darbuotojo ir jo darbovietès santykio sriti, siekè 73 ir beveik prilygo geriausiai pasaulyje šiuo aspektu vertinamoms bendrovèms. Tačiau naujausias darbuotojų prieraišumo tyrimas rodo, kad pastaraisiais metais Lietuvos darbuotojų lojalumas kiek sumažèjo. 2005 m. atitinkamas Lietuvos darbuotojų prieraišumo rodiklis siekè 48 balus, o 2007 m. pradžioje sumažèjo iki 44 . Vertinant pasaulio tendencijas, $2006 \mathrm{~m}$. tik 10 proc. pasaulio bendrovių indekso reikšmè buvo didesnè nei 78, o prasčiausiai ịvertintų bendrovių indekso reikšmè - 39 balai. Palyginti su kitomis šalimis, Lietuvos darbuotoju prieraišumo indeksas yra mažesnis nei pasaulyje ir Europoje, šiuo požiūriu Lietuvą lenkia ir kitos Baltijos šalys. Pasaulyje ir Europoje prieraišumo indekso vidurkis siekia 59. Šiuo metu Lietuva atsilieka nuo Latvijos, joje darbuotojų prieraišumas vertinamas 52, ir nuo Estijos - šios šalies indeksas siekia 55. Pastarųjų kelerių metų duomenimis, pasaulyje gana dideliu darbuotojų prieraišumu pasižymi Lotynų Amerikos valstybès, jose minètas indeksas siekia 68. JAV darbuotojų prieraišumas vertinamas 61 , o sparčiai augančio ūkio Kinijoje - 51. Reikia pažymèti, kad mažais darbuotojų prieraišumo rodikliais pasižymi ir tokios išsivysčiusios šalys, kaip Pietų Korèja, joje prieraišumo vertinimas tesiekia 39, ir Kinijos dalis Honkongas - prieraišumo indeksas yra 27 (Matuliauskas 2007).

Žemas indeksas rodo, kad darbuotojams jų darbo sąlygos yra nepatrauklios, o ir ịmoné jiems nèra svarbi. „TNS Gallup" tyrimų duomenimis, darbuotojai, kurių prieraišumo rodikliai yra aukštesni, yra linkę labiau siekti visos organizacijos tikslų, o ne vien tik savo asmeninių. Kuo mažesnis prieraišumo indeksas, tuo daugiau pasitaiko dienų, kai darbuotojai vengia eiti ị darbą. Lietuvoje labiausiai vertinamas profesionalus, nereiklus ir pasižymintis pozityviu mąstymu darbuotojas. 2006 m. atlikti „TNS Gallup“ tyrimai rodo, kad lietuviams kol kas svarbiausi yra materialinio ar momentinio skatinimo būdai: premija ar mènesiniai priedai, priklausantys nuo pasiektų rezultatų (Matuliauskas 2007). Anot ekspertų, šalyje kol kas nepopuliarios yra ilgalaikès motyvavimo priemonès, kurios darbuotojus ir įmonę susieja ilgam laikui, pavyzdžiui, mokèdamos už darbuotoją i̇mokas i pensijų fondą ar suteikdamos galimybę isigyti akcijų. Formuojant organizacijos kultūrą ir tradicijas turi būti stiprinamas priklausymo kolektyvui jausmas.

\section{Darbuotojų konkurencingumo ir jo didinimo vertinimo galimybès}

Imoneje, norint užtikrinti kuo našesnį darbą, objektyviai motyvuoti ir ịvertinti darbuotojus, tikslinga sudaryti tinkamą organizacinę struktūrą (pasitelkiant organizacinių struktūrų teoriją) - nustatant aiškų pavaldumą, funkcijas, darbuotojų vertintojus. Taikant darbo organizavimo teoriją (stabilizuojamąsias priemones - darbo vietų organizavimo projektą), galima užtikrinti sklandų, efektyvų darbą.

2 lentelè. Darbuotojų konkurencingumui vertinti taikomi metodai (Klupšas 2006)

Table 2. Methods Applied to Assess Employee’s Competitiveness (Klupšas 2006)

\begin{tabular}{l|l}
\hline Interviu & $\begin{array}{l}\text { Nustatomas darbuotojo komunikabilumas, darbinès veiklos charakteristikos, lojalumas, } \\
\text { motyvacinės ypatybės. }\end{array}$ \\
\hline Psichologinis testavimas & İvertinamos asmenybès savybės, intelektas ir kitos charakteristikos \\
\hline Profesinis testavimas & $\begin{array}{l}\text { İvertinamas asmens tinkamumas konkrečiai darbo vietai, būtinų sugebejjimų, žinių, } \\
\text { kompetencijų lygis }\end{array}$ \\
\hline Praktinių užduočių atlikimas & İvertinamas asmens, atliekančio vieną ar kitą užduotị, elgesys \\
\hline
\end{tabular}


Reglamentuojamosios priemonės (darbuotojų pareiginès instrukcijos; personalo kompetencijos planavimo ir vertinimo nuostatos; darbuotojų kvalifikacijų pripažinimo tvarka) padeda nustatyti aiškius reikalavimus konkrečioms pareigybėms, tai palengvina darbuotojų vertinimo procesą ir galimybę siekti karjeros. Nors organizacija mokosi tik tuomet, kai mokosi atskiras individas, tačiau pavienis mokymasis negarantuoja, kad visa organizacija ims mokytis (Savanevičienè et al. 2008). Tam reikalingos papildomos organizacinès sąlygos.

Vertinant darbuotoją, jo kompetencijas ar konkurencingumą dažniausiai taikomi kokybiniai vertinimo metodai (aprašomojo pobūdžio) (2 lentelè). Populiarèja 360 laipsnių grị̌tamasis ryšis - informacija renkama iš vadovų, pavaldinių, kolegų ir klientų. Šis metodas pats efektyviausias, tačiau dažniausiai taikomas sprendžiant kvalifikacijos kèlimo problemas, o ne atlyginimo padidinimo klausimus (Alonderiené, Bakanauskienè 2004; Darbuotojų kompetencijų... 2009).

Tačiau taikant kokybinius metodus darbuotojo savybẻms vertinti, gaunami rezultatai nèra išsamūs. Kalbant apie pagrindinius kiekybinius metodus, kuriuos galima būtų taikyti analizuojant darbuotojų konkurencingumą, tikslinga paminèti keletą (3 lentelè).

Taigi ne visi metodai yra vienodai tinkami, darbuotoją reikètų vertinti kompleksiškai, tarpusavyje derinant keletą tiek kiekybinių, tiek kokybinių metodų, kur galètų būti taikomas daugiatikslis - daugiakriterinis vertinimo modelis (Zavadskas et al. 2008). Tarp pateiktų darbuotojų konkurencingumo analizèje taikytinų kiekybinių metodų dalis jų - matematiniai metodai (matematinis programavimas, tinklinis metodas, jautrumo analizè, scenarijų metodas) paprastai nèra taikomi, bet galètų būti naudingi sprendžiant su darbuotojų konkurencingumu susijusias problemas, išsamiau analizuojant šią temą. Kalbant apie pačių darbuotojų vertinimą, dažniausiai įmonėse naudojamas darbuotojų testavimas, lyginimas su bendradarbiais, rečiau taikomas kitas metodas - kai iškeliami reikalavimai atitinkamai pareigybei ir jiems priskiriami balai ar koeficientai prioriteto tvarka, o darbuotojai ranguojami pagal atitiktį šiems reikalavimams.

Analizuojant darbuotojų konkurencingumą, jo didinimo galimybes, tikslinga būtų pritaikyti ekonomikoje taikomus metodus.

Visų pirma, paminètina finansų teorija (Makštutis 1999). Ja remiantis galima nustatyti, iš kokių šaltinių darbuotojas turètų kelti savo kvalifikaciją, mokytis, didindamas savo konkurencingumo potencialą. Išoriniai finansavimo šaltiniai galètų būti ịvairūs:

- Tai darbdavių, ES projektų ar valstybès parama. İmonè, savo lèšomis apmokèjusi už darbuotojų studijas aukštojoje ar aukštesniojoje mokykloje, igyja teisę šiomis sumomis mažinti pelno mokestị. Naudinga ir tai, kad darbuotojo išsilavinimui ir kvalifikacijai skirtos sumos neapmokestinamos nei gyventoju pajamų mokesčiu, nei valstybinio socialinio draudimo imokomis.

- Taip pat galima finansuoti kvalifikacijos kèlimą paskolomis (pvz., iš banko, iš draugų, šeimos narių). Tačiau už paskolą reikès mokèti palūkanas, paskolos tvarkymo mokestị, būtina turèti ịsipareigojimo ịvykdymą užtikrinančių priemonių (kai kurių mokymo kursų, kurie vykstą užsienyje, kaina yra labai didelè).

- Vidiniai šaltiniai - tai darbuotojo santaupos, einamosios pajamos, palikimas ar pan.

Antra, pelno paskirstymo metodai - juos taikydama įmonè dali pelno skirtų investicijoms i̇ žmogiškuosius išteklius, tokiu būdu tiesiogiai finansuodama ne tik atskiro darbuotojo kvalifikaciją, bet ir prisidedama prie visos įmonès konkurencingumo didinimo.

Dar vienas būdas - tai efektyvumo vertinimo metodai. Juos galima būtų pritaikyti vertinant organizacijos investa-

3 lentelè. Darbuotojų konkurencingumo analizeje taikytini kiekybiniai metodai

Table 3. Quantitative Methods Applied to Analyse Employee's Competitiveness

\begin{tabular}{|c|c|}
\hline Matematinè statistika & Apdoroti statistinius darbuotojų charakteristikų duomenis \\
\hline Daugianarė koreliacinè regresinė analizė & Nustatyti, nuo kokių veiksnių ir kaip priklauso darbuotojo konkurencingumas \\
\hline Matematinis programavimas & $\begin{array}{l}\text { Pvz., skaičiuojant kiek } 1 \mathrm{Lt} \text {, investuotas ị darbuotojo mokymą, padidina } \\
\text { pardavimo apimtị }\end{array}$ \\
\hline Tinklinis metodas & $\begin{array}{l}\text { Galètų būti pritaikomas apskaičiuojant, kiek laiko, kiek vertintojų ir kokiu } \\
\text { nuoseklumu turètų atlikti darbuotojo vertinimą }\end{array}$ \\
\hline Scenarijų metodas, jautrumo analizè & $\begin{array}{l}\text { Galètų būti taikomas analizuojant, kaip keistųsi Lietuvos darbuotojo } \\
\text { konkurencingumas ar išsilavinimas, jị lemiantiems veiksniams keičiantis ị } \\
\text { gerąją ar blogąją pusę }\end{array}$ \\
\hline Ekspertiniai vertinimai & Vertinant darbuotojų konkurencingumą įmonèje ar valstybės mastu \\
\hline
\end{tabular}


vimo ị savo darbuotojų konkurencingumo didinimo efektyvumą (Makštutis 1999):

- Techniné analizė - nagrinėja potencialą, koks yra dabar darbuotojo konkurencingumas ir koks bus, investavus i jo mokymus.

- Finansinè analizė - mokymo kursų atsipirkimo laiką.

- Ekonominè analizè - investavimo į žmogiškuosius išteklius sąnaudas, naudą, sąnaudų ir naudos santykị, išlaidų vertingumą, šių rodiklių santykinius dydžius ir dinamiką.

- Rizikos analizè - prieš investuodama ị savo darbuotojų mokymus, siųsdama juos ị ịvairias stažuotes, seminarus, apmokèdama iš savo lèšų, organizacija turètų ịvertinti riziką, kad darbuotojas, pakèlęs savo kvalifikaciją, kompetenciją, gali palikti įmonę ir išeiti pas kitą darbdavị, kuris jam pasiūlys geresnị atlyginimą ar motyvavimo sistemą. Tad būtina apsidrausti ir numatyti, kad darbuotojas, išejęs iš įmonès, turètų atlyginti su mokymu susijusias išlaidas (šis metodas atskirais atvejais jau taikomas seniai).

Paminètina ir vidinè ūkiskaita, kai nustatomi organizacijos viduje tokie santykiai, kurie padeda kiekvienam padaliniui būti skatinamam siekti geresnių rezultatų (turèti daugiau pelno arba mažiau sąnaudų). Tokiu būdu nustatoma visa pelno ar išlaidų struktūra ir dirbtinai nustatomi atitinkami rodikliai, kaip kiekvienas padalinys turi siekti geresniu rezultatų. Nustatoma, laikantis principo „kiek uždirbsim - tiek ir gausim“. Be abejo, po vertinimo proceso labai svarbu parinkti tinkamus darbo apmokejjimo metodus.

\section{Išvados}

1. Susisteminus pastarųjų penkerių metų îvairių autorių atliktus tyrimus, pabrěžtina, kad autoriai ne visur atskiria sąvokas kvalifikacija, kompetencija, konkurencingumas. Dauguma savo tyrimuose naudojo anketinę darbuotojų ir darbdavių apklausą, interviu, ekspertinius vertinimus ir sisteminę analizę. Vertindami darbuotojų kompetencijas, daugelis autorių išskiria tarpkultūrinès, neformaliosios kompetencijos svarbą šiuolaikinès globalizacijos metu bei komunikavimo kompetenciją ir pabrēžia, kad nustatant kompetencijas būtinas kritiškas požiūris, nes jos vertinamos statikos būklès, neatsižvelgiant ị būsimą kompetencijų poreikị, kurios gali būti reikalingos, kai darbuotojas nori išlaikyti esamą poziciją i̇monèje bei siekia karjeros. Prieinama prie bendros nuomonès, kad Lietuvos organizacijose dar trūksta aiškiai nustatytų karjeros planavimo, pareigybių reikalavimų bei standartų.

2. Išanalizavus darbuotojo konkurencingumo vertinimo aspektus, pastebeta tiek kokybinių, tiek kiekybinių metodų ịvairovè ir galimas jų pritaikomumas išsamiau nagrinėjant problemą (nustatant darbuotojų charakteristikas, prognozuojant tolesnę situaciją, siekiant konkurencingumo; ivertinant, kiek darbdaviams naudinga didinti personalo kompetenciją) ir vertinant pačius darbuotojus (pasitelkus kiekybinius metodus, galima pasiekti daugiau aiškumo, tikslumo ir objektyvumo, nustatant konkurencingumo sudedamąsias dalis ir darbuotojų atitiktị keliamiems reikalavimams). Tačiau dauguma įmonių taiko tik kokybinius vertinimo metodus, o didžiausia kliūtis tinkamai įvertini darbuotojo konkurencingumą - subjektyvumas (vertintoją gali veikti stereotipai, išankstiniai nusistatymai, ankstesni darbo rezultatai).

3. Be subjektyvumo, išskiriami ir kiti veiksniai, kurių vieni daro įtaką vertintojui ir vertinimo procesui (vertintojų kompetencijos stygius, laiko ir lèšu trūkumas, sudarant tikslius pareigybių aprašus, standartus), o kiti skatina arba trukdo darbuotojui būti konkurencingam ir siekti jo didinimo rinkoje (pajamos, kurias gali skirti savišvietai, šeimos palaikymas, visuomenejje vyraujantis požiūris, prestižas turèti mokslo laipsnį, švietimo sistema, vidinė organizacijos kultūra, deklaruojamos vertybès, migracijos ir globalizacijos, sukelta išorinè ir vidinè konkurencija tarp darbuotojų, nuolatinė naujų technologijų kaita ir besiplečianti aptarnavimo sfera).

4. Pabrèžtina, kad vertinant darbuotojų konkurencingumą tikslinga taikyti keletą tiek kokybinių, tiek kiekybinių metodų, siekiant tiksliau nustatyti esamą būklę, o analizuojant konkurencingumo didinimo galimybes siūloma pritaikyti ekonomikoje taikomus metodus, tokius kaip finansų teorija, pelno paskirstymo, efektyvumo vertinimo metodus, ir net vidinę organizacijos ūkiskaitą.

5. Atliekant tolesnius darbuotojų konkurencingumo vertinimo tyrimus, reikètų prognozuoti, kaip ateityje keisis darbuotojo konkurencingumas ir ji veikiantys veiksniai, nustatyti Lietuvos darbuotojo vietą (rangą) tarp kitų šalių (pvz., Baltijos regiono) darbuotojų pagal vieną ar kelis kriterijus. Atlikus anketinę darbuotojų apklausą, galima būtų sužinoti, kaip save vertina patys darbuotojai, galbūt jiems yra tekę konkuruoti dẻl darbo su kitų šalių piliečiais. Taip pat būtų naudinga sužinoti, ką darbdaviai labiau vertina: darbuotojų patirtị ar išsilavinimą (kaip konkurencingumo elementą).

\section{Literatūra}

Alonderienė, R.; Bakanauskienė, I. 2004. Darbuotojų vertinimas komandose, Organizaciju vadyba: sisteminiai tyrimai [Management of Organizations: Systematic Research] 30: 21-33.

Balčiūnas, S.; Rudytė, D.; Šeputienė, J. 2006. Finansų specialisto profesinès kompetencijos vertinimas banko darbuotojo, einančio vadovo pareigas, požiūriu, Socialiniai tyrimai [Social Research] 2(8): 106-113. 
Bersènaitè, J.; Saparniené, D.; Saparnis, G. 2009. Darbuotojų vaizdinių psichosemantika nustatant pokyčių ir sèkmingos organizacijos dimensijas, Inzinerine Ekonomika - Engineering Economics (5): 67-78.

Bivainis, J.; Morkvėnas, R. 2008. Darbuotojų žinių potencialo vertinimas, Verslas: teorija ir praktika [Business: Theory and Practice] 9(2): 105-115. doi:10.3846/1648-0627.2008.9.105-115

Boreišaitè, R.; Pikžirnytė, I.; Chreptavičienè, V. 2006. Darbuotojo kompetencijų poreikis globalizacijos kontekste, iš 4-osios studentu mokslinés konferencijos medžiaga. Kaunas: Technologija, 12-14.

Budaitè, R.; Petkevičiūtè, N. 2005. Vadovų tarpkultūrinè kompetencija Lietuvos organizacijose, Organizacijų vadyba: sisteminiai tyrimai [Management of Organizations: Systematic Research] 36: 133-150.

Buožiūtė-Rafanavičienè, S.; Pundžienè, A.; Turauskas, L. 2009. Ryšys tarp naujojo vadovo charakteristikų ir organizacijos veiklos rezultatų, Inzinerine Ekonomika - Engineering Economics (2): 65-74.

Clarke, Mary. 2009. Preparing now for a successful workforce, Financial Executive 25(7): 43-46.

Čepinskis, J.; Rudytė, D. 2007. Finansų specialistų žinių poreikio ivertinimas, Organizaciju vadyba: sisteminiai tyrimai [Management of Organizations: Systematic Research] 44: 89-106.

Čiarnienè, R.; Kumpikaitè, V. 2008. New training technologies and their use in training and development activities: survey evidence from Lithuania, Journal of Business Economics and Management 9(2): 155-159.

doi:10.3846/1611-1699.2008.9.155-159

Darbuotoju kompetenciju vertinimas. UAB OVC Consulting [interaktyvus] [žiūrèta 2009-09-17]. Prieiga per internetą: $<$ http://www.ovc.lt/lt/ovc-consulting-paslaugos/paslaugusritys/personalo-valdymas1.html>.

Darškuvienè, V.; Kupelytė, D.; Petkevičiūtè, N. 2008. Vadybinès kompetencijos nustatymo galimybès mokymo procese, Organizaciju vadyba: sisteminiai tyrimai [Management of Organizations: Systematic Research] 45: 17-28.

Daugèlienè, R.; Marcinkevičienè, R. 2009. Protų cirkuliacija: teoriniai svarstymai, Inzinerine Ekonomika - Engineering Economics (3): 49-57.

Daukšienė, E.; Pribušauskaitè, J.; Teresevičienė, M. 2008. Konsultanto pasirengimo ir jo asmeninių savybių svarba darbuotojų kompetencijų vertinimo procese, Organizacijų vadyba: sisteminiai tyrimai [Management of Organizations: Systematic Research] 45: 85-98.

Dobson, J.; Sennikova, I. 2007. From fundamental freedom to political and economic 'Hot Potato' In 50 Years: labour mobility and migration within the EU, Journal of Business Economics and Management 8(2): 123-136.

Gedvilienè, G.; Kuncaitis, R. 2008. Darbuotojų gebejjimai dirbti grupèse, igyti savaiminiu būdu universitetinèse studijose, bei tų gebejjimų plètojimo modelis, Organizacijų vadyba: sisteminiai tyrimai [Management of Organizations: Systematic Research] 45: 29-45.

Ginevičius, R.; Ginevičienè, V. B. 2009. The compliance of master's degree studies with the economic needs of the country,
Technological and Economic Development of Economy 15(1): 136-153. doi:10.3846/1392-8619.2009.15.136-153

Gruževskis, B.; Pocius, A.; Moskvina, J. 2007. Lietuvos darbo rinka: vystymosi tendencijos, problemos ir galimi sprendimai. Pirmojo mokslinio tyrimo etapo ataskaita. Vilnius: Darbo ir socialinių tyrimų institutas.

Gudas, S. 2009. Enterprise knowledge modelling: domains and aspects, Technological and Economic Development of Economy 15(2): 281-293. doi:10.3846/1392-8619.2009.15.281-293

Gudauskaitè, S. 2007. Žinių visuomenès link: organizacijos darbuotojo kompetencijų poreikis, Informacijos mokslai [Information Sciences] 40: 66-71.

Gudžiūnienè, N. 2006. Vadybininko kompetencijos vertinimas komunikavimo ir konfliktų sprendimo, Vadyba. Mokslo tiriamieji darbai [Management. Scientific Research Works] 1(8): 19-23.

Janušauskas, A.; Makštutis, A. 2007. Žmogiškųjų išteklių kiekybinio ir kokybinio vertinimo sistemos tobulinimas, Personalo vadyba [Personnel Management. Science Works] 2(78): 12-20.

Juodvalkytè, D. 2006. Profesionaliai ịvertintas personalas - darbo efektyvumo garantas, Verslo labirintas [Business Labyrinth] 2(41): 51-54.

Keršienè, K.; Savanevičienè, A. 2009. Organizacijos tarpkultūrinès kompetencijos formavimas ir valdymas žvelgiant iš tarpkultūrinès perspektyvos, Inzinerine Ekonomika - Engineering Economics (5): 56-66.

Klupšas, F. 2006. Darbuotoju veiklos vertinimo aktualijos [interaktyvus]. Lietuvos žemès ūkio universitetas [žiūrèta 2009-11-30]. Prieiga per internetą: <http://baitas.lzuu.lt/ $\sim$ mazylis/julram/7/62.pdf $>$.

Kumpikaitè, V. 2007. Žmonų išteklių mokymo vertinimas [Human Resource Training Evaluation], Inzinerine Ekonomika - Engineering Economics (5): 29-36.

Kumpikaitè, V. 2008. Human resource development in learning organization, Journal of Business Economics and Management 9(1): 25-31. doi:10.3846/1611-1699.2008.9.25-31

Lobanova, L. 2009. Žmogiškųjų išteklių vadybos vertė žiniomis grindžiamoje visuomenejje [Human Resources Management Value in Knowledge-Based Society], Verslas: teorija ir praktika [Business: Theory and Practice] 10(3): 233-246. doi:10.3846/1648-0627.2009.10.233-246

Lobanova, L.; Pelekaitè, A.; Radzevičiūtè, J. 2009. Competences of human resources management: expectations and reality, Ekonomika [Economics] 86: 22-40.

Makštutis, A. 1999. Veiklos vadyba: teorija ir praktika [Business Management: Theory and Practice]: monografija. Vilnius: Leidybos centras. $523 \mathrm{p}$.

Matuliauskas, A. 2007. Ištikimi nelyginant samurajai [Loyal Like Samurai], Verslo klase [Business Class] 1: 34.

Minton-Eversole, T. 2009. Skills deficiencies threaten United States' workforce competence, HR Magazine 54(9): 2-3.

Mokymo funkcijos stiprinimas ir plètra darbuotoju konkurencingumo ugdymui. Lietuvos 2004-2006 m. bendrasis programavimo dokumentas [interaktyvus] [žiūrèta 2009-09-15]. Prieiga per internetą: <http://www.esparama.lt/lt/bpd/ zemelapis/ id $=341>$. 
Petkus, T.; Filatovas, E.; Kurasova, O. 2009. Investigation of human factors while solving multiple criteria optimization problems in computer network, Technological and Economic Development of Economy 15(3): 464-479. doi:10.3846/1392-8619.2009.15.464-479

Rostamy, A. A. A. 2009. Toward understanding conflicts between customers and employees' perceptions and expectations; evidence of Iranian bank, Journal of Business Economics and Management 10(3): 241-254. doi:10.3846/1611-1699.2009.10.241-254

Rutkienè, A.; Teresevičienè, M.; Zuzevičiūtė, V. 2006. Tęstinis profesinis mokymasis: sankirtos ir prieštaros, Organizaciju vadyba: sisteminiai tyrimai [Management of Organizations: Systematic Research] 40: 203-217.

Savanevičienè, A.; Stukaite, D.; Šilingiené, V. 2008. Individo strateginių kompetencijų ugdymas, Inzinerine Ekonomi$k a$ - Engineering Economics (3): 81-88.

Skučienè, A. 2008. Absolventų igytų kompetencijų vertinimas darbo rinkos atstovų požiūriu, Taikomieji tyrimai studijose ir praktikoje [Applied Research in Studies and Practice] 1: 35-42.

Stankevičienè, A.; Liučvaitienè, A.; Volungevičienė, D. 2008. Ugdymo principo taikymo galimybès personalui mokyti, Verslas: teorija ir praktika [Business: Theory and Practice] 9(3): 199-209. doi:10.3846/1648-0627.2008.9.199-209

Stasiūnaitienè, E. 2008. Neformaliojo ir savaiminio mokymosi pasiekimų vertinimo ir kompetencijų pripažinimo sistemos organizavimas, Organizaciju vadyba: sisteminiai tyrimai [Management of Organizations: Systematic Research] 45: $57-70$.
The Multigenerational Workforce: Opportunity for Competitive Success, 2009, HR Magazine 54(3): 1-9.

TRI ${ }^{\star} M$ - imonés interesu grupiu valdymas. UAB TNS Gallup tyrimai [interaktyvus] [žiūrèta 2009-10-20]. Prieiga per internetą: <http://www.tns-gallup.lt/lt/musu-kompetencijatyrimu-sprendimai-verslui-trim-imones-interesu-grupiuvaldymas $>$.

Vasiliauskas, A. 2004. Strateginis valdymas [Strategic Management]. Kaunas: Technologija, 383 p.

Zakarevičius, P.; Žukauskas, P. 2008. A comparative study of managers'career factors in selected EU countries, Transformations in Business and Economics 7(2): 84-97.

Zakarevičius, P.; Župerkiené, E. 2008. Vadovų asmeninių ir dalykinių savybių ugdymo tobulinimas, Inzinerine Ekonomika - Engineering Economics (5): 104-113.

Zavadskas, E. K.; Turskis, Z.; Tamošaitienė, J.; Marina, V. 2008. Multicriteria selection of project managers by applying grey criteria, Technological and Economic Development of Economy 14(4): 462-477. doi:10.3846/1392-8619.2008.14.462-477

Zinkevičiūtè, V. 2006. Darbuotojų kompetencija - strateginių sprendimų kokybès sąlyga, iš Investicijos $j$ žmogiškuosius išteklius: konkurencinio pranašumo siekis. Tarptautines mokslines konferencijos, jvykusios Vilniaus teises ir verslo kolegijoje 2006 m. gegužès 4 d., medžiaga. Vilnius: Vilniaus teisès ir verslo kolegija, 152-159.

Daiva JUREVIČIENĖ. Doctor of Social sciences, Department of Financial Engineering, Vilnius Gediminas Technical University. Research interests: personal finance, investment, banking, risk management.

Aleksandra KOMAROVA. Master's student of Management and Business Administration. Department of Financial Engineering, Vilnius Gediminas Technical University. 